\title{
Black Consciousness, Black Nationalism and Black Theology: Is there a possibility for theology of dialogue?
}

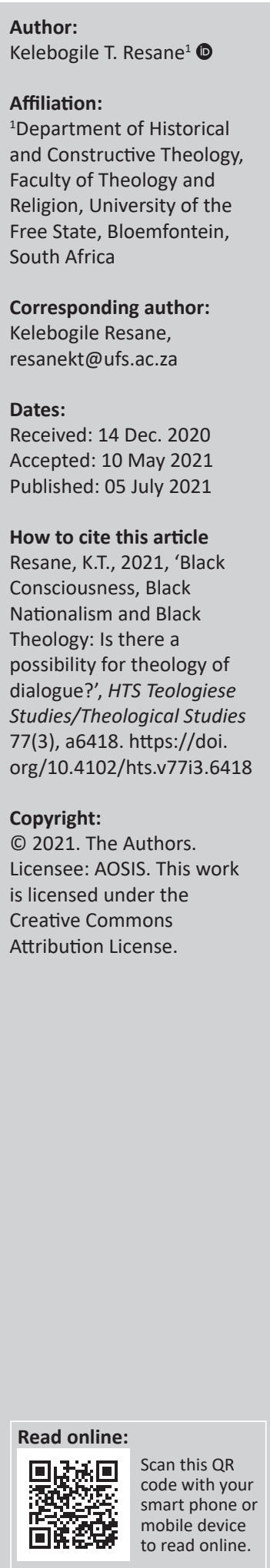

This article gives some historical development of Black Consciousness, Black Nationalism and Black Theology during the colonial and apartheid eras. The three worked symbiotically to address the racial injustices of the past. Each tenet is historically explained and ideologically defined. Black Consciousness and Black Nationalism are still prevalent in the South African sociopolitical landscape. This is expressed through the current political parties that are the minorities in the National Assembly. However, the ruling party, African National Congress (ANC), as a 'broader church' also possesses some constituents and adherents who are the Black Consciousness and Nationalistic aspirants. South Africa is developing into a peasant society regardless of capitalistic embraces of development. Poverty and equality are visible in societal structures. Those who were formerly equality aspirants are now in sociopolitical and economic circles and had forgotten their aspirations of justice and equality. Corruption, maladministration, bad governance, etc., are the menaces that cause imbalances and create a wider gap between the rich and the poor.

Contribution: Black Theology is invited to lead dialogical deliberations to assess and ascertain how to bring justice into the volatile situation where people's security and safety is uncertain and warped ideologies such as ethnic cleansing are promoted. Black Theology should resort to the theological mandate of speaking for the poor and oppressed and promote the sense of the New Testament spirit of communality.

Keywords: black consciousness; black nationalism; black theology; dialogue; equality; social justice; colonialism; apartheid; democracy.

\section{Introduction}

South Africa is a society that is consciously still seeking to reconstruct its identity and selfdefinition in the unfortunate context that seeks to perpetuate old paradigms of racial segregations. The erratic isolated incidents of racial slurs demonstrate that the nation is still on the path of recovery from the racial injustices of the past. Some ideologies associated with these paradigms remain a threat to the national sense of security for both individuals and groups alike. Netshitenzhe (cited in Kornegay \& Mthembu 2020) correctly points out that:

$[T]$ here will be ongoing internal tensions, both open and subliminal, as the sense of pride and the drive towards self-improvement wrestle with an overemphasis on blame-shifting and rationalisation of dependency. (p. 38)

The objective of this article is to do some historical analysis of three main historical forces that emerged as proposals for dealing with racial injustices, especially racial inequality. These three are Black Consciousness, Black Nationalism and Black Theology. The intention is to demonstrate how the three stood symbiotically against colonial misnomers, and how the postapartheid era swallowed them into some absence. The call is made to Black Theology to assert itself by initiating a theology of dialogue for these partners to deliberate on balancing the current injustices with theological sanity towards social justice.

\section{Black Consciousness}

One of the tensions referred to in this article is the historical Black Consciousness, misinterpreted and misrepresented by some people 'as supportive of the policy of apartheid and those who think about Black Consciousness as racially exclusive, but nothing could be further from the truth' (Dolamo 2017:3). In particular, the liberals assumed that this demand for separation

Note: Special Collection: VukaniBantuTsohangBatho: Spirituality of Black Liberation, sub-edited by Fundiswa Kobo (University of South Africa) and Rothney Tshaka (University of South Africa). 
between whites and blacks sounded uncomfortably similar to apartheid in reverse (Thomas 2002:203). This is refuted by reading through a number of documents of the 1970s regarding Black Consciousness, whereby one can conclude that this is black people's self-understanding and pride in the colour of their skin, and that they should appreciate their value as human beings. One of the organisations through which Black Consciousness was expressed and conveyed was South African Students Organisation (SASO) founded in 1968. It was the 'earliest concrete manifestation of South African Black Consciousness, and thus the first of an array of organisations forming the Black Consciousness Movement' (Kenworthy 2007:41). According to the Black Sash magazine of August 1976, SASO defined Black Consciousness as:

- Black Consciousness is an attitude of mind, a way of life.

- The basic tenet of Black Consciousness is that the black man must reject all value systems that seek to make him a foreigner in the country of his birth and reduce his basic human dignity. The black man must build up his own value systems and see himself as self-defined and not defined by others.

- The concept of Black Consciousness implies awareness by black people of the power they wield as a group, both economically and politically and hence group cohesion and solidarity are important facets of Black Consciousness.

- Black Consciousness will always be enhanced by the totality of involvement of the oppressed people; hence, the message of Black Consciousness has to be spread to reach all sections of the black community.

Black Consciousness can be described as an awareness amongst black people that their human identity hinges on the fact that they are black. Black people are proud of their skin colour, and aware of the fact that they have their own black history and culture, differing from those of whites. They no longer accept being judged according to white values and norms. In essence, Black Consciousness is an attitude towards life. It is very difficult, if not impossible, for white people to be included in Black Consciousness groups, as this philosophy 'has sought to position itself as an anticipatory, reflexive moment of Black selfconsciousness in the face of White superiority and White supremacy' (Cloete 2016:37). This was confirmed by Biko (1978:92) that Black Consciousness 'is an attitude of mind and a way of life, the most positive call to emanate from the black world for a long time'. The concept goes to assert further that black people should be aware of their own cultural value systems including their socio-economic and political values. This means that black people should reject with utter contempt the foreign value systems forced upon them by the oppressors and opt to embrace, rather than maintaining and perpetrating the brutal imperial system of exploitation and disempowerment. ' $[t]$ he culture of the people was declared barbaric and the people were regarded as savages and the Western culture was imposed on them' (Dolamo 2014:218). In reaction to this subjugation, Black Consciousness emerged as an inspiration for Black people to search out their value systems that were despised by the colonialists with the intention of cultural assimilation and subjugation. During his court trial, Kaborane Gilbert Sedibe, the President of the Student Representative Council of the University of the North (now University of Limpopo) gave the definition of Black Consciousness Movement as 'not just as resistance ideology; it was about dignity - about the essential wholeness of a singular being who knew himself (Magaziner 2010:7). The movement emerged as a search for identity as a self-defence against an oppressive regime, discriminatory and exploitative apartheid system. In the eyes of the black nationals, this system was championed and promoted by the imperialist white minority, cooperating with some mission boards to foster the segregationist ideals. As Thomas (2002:202) says: ' $i$ i] was an aggressive assertion by blacks themselves of their equality and human worth, summed up in the statement: "Black is Beautiful"".

Black Consciousness is the call for cohesive group solidarity that employs the concept of group power contributing towards a strong base from which to counter the oppressor's policy of divide and rule (apartheid). One famous proponent of Black Consciousness is Biko (1978), and regarding this solidarity, he declared:

[T] he realisation by blacks of the need to rally around the cause of their oppression - the blackness of their skin - and to operate as a group to rid themselves of the shackles that bind them to perpetual servitude. (p. 100)

Lamola (2016:184) is correct when he says that Black Consciousness has emanated from perspectives that are largely driven by the goal of political activism, and its emphasis on liberation from colonial mentality and alienation of black personhood. As a Pan-Africanist ideology, its vision is unity, solidarity and a common African destiny (Motaung et al. in Kornegay \& Mthembu 2000:56). Its ideal was a non-racial democracy, with priority of organising non-white people into a movement that fostered black pride and self-confidence (Giliomee 2003:564).

The philosophy of Black Consciousness, therefore, is a group pride and self-determination by black people in South Africa to fight together against oppression and exploitation. It calls black people not only to go beyond the slogans of mere verbal assertions but also to practically experience consciousness as an existential reality. The oppressed are called upon to believe in self-reliance by practically engaging in social self-upliftment practically.

In the early seventies, the educational programmes were launched to introduce the message of self-reliance and Black Consciousness to high-school students and township youths throughout the country (eds. Pityana et al. 1992:215). This was made practical by the launching of the Black People's Convention (BPC) 'to expand the work of Black Consciousness beyond the student and youth groups of $\mathrm{SASO}^{\prime}$ and get the masses involved (eds. Pityana et al. 1992:52), and the Black Community Programmes (BCP) 'to give practical effect to the philosophy of self-reliance' (Ramphele 1995:94). 
These BCP covered the fields of health, education, leadership training, publications, home industries and childcare (eds. Pityana et al. 1992:157). The Black Consciousness Movement was also influential because of its 'strategic use of the media' which was part of the reason why the Black Consciousness Movement and Steve Biko became recognised as 'a key political voice by members of the international community' that subsequently began consulting him on issues regarding South Africa (eds. Pityana et al. 1992:59, 128).

Black Consciousness is also the realisation by black people that the most powerful and effective weapon against oppression and exploitation by the oppressor is the mind of the oppressed. In South Africa, the oppressive apartheid regime attempted to twist and manipulate black minds in order to make black people mentally and psychologically pliable to the regime's exploitation and manipulation tactics. Black Consciousness therefore calls for a psychological and emancipatory revolution in and for the development of the black community. This revolution was to be directed towards the elimination of all self-defeat mentalities by black people about themselves, and one directed towards the complete eradication of the slavementality and feelings of inadequacy characteristic of an oppressed and exploited society. Jordan (2007:xxvii) decries the fact that demoralised slaves are forever on their knees before their masters are unlikely to fight for and win their freedom. The basic logic inherent in Black Consciousness is the war of liberation to effectively eradicate slave-mentality and welcome self-acceptance as fully human possessing capacity in one's own emancipation. It is when black persons come into consciousness, whereby they engage with and embrace the challenges of creating, and being in a culture in which people are experienced not as racial beings but as rational beings (Lamola 2016:193). This means that blacks must psychologically liberate themselves from the 'slave mentality' created by 'institutionalised racism' and 'white liberalism'. Black Consciousness therefore forces black people to see themselves as full human beings, complete and total in themselves and not as extensions of others. It has become 'the first truly non-racial experience for millions of South Africans' (Boesak 2005:9). Black Consciousness is all about human dignity - the anthropological perspective that is doctrinally consonant with created people as creatures carrying the image of God. Mbembe (2017:30) summarises it well that it is a resistance largely driven by international anarchism, the principal vehicle opposing capitalism, slavery and imperialism.

\section{Black Nationalism}

Black Nationalism is the precursor to modern African nationalism:

$[B]$ egun as an attempt by African nationalities to not submit to European rule during the scramble for Africa. When that failed, the nationalities, now grouped under new multination states created by colonialism, reorganised under the leadership of the new, more radical Western-educated elite (the nationalists) to terminate colonial rule. And when that succeeded, the nationalists began to wrestle with the difficulties of solidifying the multination states that they inherited. ${ }^{1}$

A central theme within the colonial project was the dehumanisation of Africans; this was achieved by devaluing their histories and capacities (ed. Mkandawire 2005:5). Historically, Africans had become a broken nation, devoid of a true sense of identity. Colonialism hollowed out the essence of political, religious, ideological, cultural, social and psychological foundations of the continent (Motaung et al. cited in Kornegay \& Mthembu 2000:57). Through its vigorous dehumanisation of the so-called natives, 'people's lives were destroyed, including their geo-histories, memories of themselves' (Mahlatsi 2020:35) and they were stripped of their human dignity and a sense of selfhood.

A central idea of African nationalism is one united Africa composed of its diversities of its people. This view, according to Gerhart (1979:59), should extend beyond the borders of South Africa, making all Africans, regardless of the cultural and tribal origin, to unite as one nation, united by the blackness of their skin. This, however, became impossible, largely because of the political and ideological impracticalities of the time.

Black Nationalism in South Africa started its manifestation and climax in the 1950s. This was a consequence of the (Williams 1970):

$[H]$ istorical situation on the Eastern Frontier of the Cape Colony in the early nineteenth century. In the twentieth century, the Port Elizabeth-East London-Alice region remained a highly significant area for nationalist ideas and action, and this derived from the effects on the Xhosa of the black-white confrontation which began here 150 years earlier. In the early part of the nineteenth century, the fundamental competition for land and cattle led to White military and missionary actions which, coupled with the preaching of Christianity, promoted attitudes among the Xhosa which may be seen in all subsequent African Nationalism. (p. 379)

Black Nationalism in South Africa is not just a social philosophy, but a political movement, known in some circles as Pan-Africanism, aiming for national self-determination. African nationalism is a political aspiration for the unification of Africa (Pan-Africanism) and for national self-determination. Instead of population groups seeing themselves through their tribal identities, Africans should view themselves as nationalists. Black Nationalism is political actions and ideological elements aimed to improve the status, the rights and position of Africans in the emerging society introduced by colonialists and apartheid regime through intrusion and conquest.

Whilst SASO was at the forefront of promoting Black Consciousness ideology, another organisation called the BPC, founded in 1971, promoted Black Nationalism for 1.See https://www.encyclopedia.com/history/encyclopedias-almanacs-transcriptsand-maps/nationalism-africa. 
blacks who found themselves operating outside the ideology of separate development. From the Black Sash magazine (1976:27), one learns that its aims were:

- To unite the black people of South Africa with a view to liberating and emancipating them from both physical and psychological oppression.

- To preach, popularise and implement the philosophy of Black Consciousness and Black solidarity.

- To formulate and implement an educational policy by black people for black people.

- To create and maintain an egalitarian society where justice is meted equally to all.

- To formulate, apply and implement the principles and philosophy of Black communalism - the philosophy of sharing.

- To create and maintain an equitable economic system based on thy principle of Black communalism.

- To co-operate with existing agencies to re-orient the theological system to make religion relevant to the needs, aspirations, ideals and goals of black people.

Both Black Consciousness and Black Nationalism represent in themselves as a deliberate counter to the divisive effect of the colonialists' policy for the indigenous Africans. They are only aware of the unadvertised 'divide and rule' factor enhanced through 'separate development' built into the masterplan of institutions like tribal enclaves called homelands. The current debate on Black Nationalism in South Africa is incomplete without reference to the homelands policy. This policy was designed to deter and shift expressions of consciousness and nationalism from urban centres to conservative rural and tribal enclaves. This was another way of the National Party's self-enhancement of racial aspirations. African evolutionary politics bears witness that tribal politics is diacritical to nationalism. It is for this reason that both Black Consciousness and Black Nationalism rejected the homelands policy.

Modern Black Nationalism is a response to white political, socio-economic and biological imperialism. It is concerned about a deeply entrenched, market-driven approach that focuses on individualism that is in direct contradiction to the communitarianism of Pan-Africanism (Motaung et al. cited in Kornegay \& Mthembu 2000:57). Evolving out of African nationalism of the National Independence Movement, it is a demand for racial equality (Kohn 1965:13), a struggle against white supremacy (Sithole 1968:17). It is a cultural ideology, and a social movement based on national identity, not tribal or ethnic identities. It emphasises:

$[T]$ he collective of a specific nation. As an ideology, black nationalism holds that 'the people' in the doctrine of popular sovereignty is the nation. Nationalism ultimately is based on supporting one's own nation. ${ }^{2}$

The movement does not focus on the historical imbalances or seek for restoration of historical sociopolitical menaces. Thus, it is clearly a secondary form of resistance against 2.See https://www.sahistory.org.za/article/african-nationalism-and-working-class-popularprotests-1910-1924. marginalised black masses who are now politically emancipated, but are still suffering from psychological oppression and economic rejection. The movement promotes non-racialism, equality and non-discrimination, whereby the skin colour acts as a determinant or a significant factor in human relations and human rights.

Black Nationalism is expressed through some political formations such as the African National Congress (ANC) and others that had mostly adopted the 'equality' approach similar to Pan-Africanists with the goal of a multiracial society with equality for all. For black nationalists, once white domination is overthrown and the white man is no longer 'supremacist' or a 'normativist' but is an individual member of society, there will be no reason to hate him and he will not be hated even by the masses.

\section{Black Theology}

South African ecclesio-political history, especially from the dawn of the 20th century reveals that theology and politics were constantly in tangents - either in collusion or collaboration. Smith (cited in Ndaba et al. 2017:127) elaborates the role of Christianity in the birth and propagation of Black Consciousness. Priests, nuns, theologians, clerics and worshippers across denominations and cultures played an unassailable role in raising consciousness (Smith 2017):

From the Afrikaner renegade Beyers Naudé to the Lutheran Manas Buthelezi, from the Pentecostal razzmatazz of Allan Boesak to Europeans funding liberation using God as their cover, Christianity and $\mathrm{BC}$ are entwined like incense smoke in the apse. (p. 127)

According to some exponents of Black Consciousness, Black Theology is also an integral part of the movement. Seen against this background, it is clear that it is extremely difficult to describe precisely the philosophical underpinnings of the doctrine. The emergence of Black Consciousness was embraced and enhanced by Black Theology. Tshaka and Makofane (2010) state that Black theologians were:

[G]alvanised by the then political situation into organising themselves into being a vanguard for the black peoples' total emancipation from the political pangs into which they were plunged by white racism in South Africa. (p. 534)

Because Black Theology was seen as an aspect of the nationalist liberation struggle, it built synergy with Black Consciousness because of its contextualised approach. The two ideological forces operated as a symbiosis to fight the oppressive regime that marginalised the black masses and overtreaded social and natural justice. The symbiosis was so strong that some regarded Black Theology as a religious arm of Black Consciousness (Cone 1972:28). This critical stance of course operated in contrast with the mainstream Christian theology that supported the status quo or remained dormant in the face of human miseries that socio-politically marred black people who as members of human species are also the careers of imago Dei. Black Theology was conceptualised almost simultaneously with Black Consciousness for some of the Black Consciousness 
leaders were the same as Black Theology leaders, for example, Biko, Pityana, Motlhabi, Mosala, Maimela and Khoapa (Dolamo 2017:6). For instance, Biko (1978) noted that Black Theology:

[I]s a situational interpretation of Christianity. It seeks to relate the present-day black man to God within the given context of the black man's suffering and his attempts to get out of it ... (it is) committed to eradicating all causes of suffering as represented in the death of children from starvation, outbreaks of epidemics in poor areas or the existence of thuggery and vandalism in townships. (p. 59)

Biko demonstrated his theological commitment and interest by continuing his membership with University Christian Movement (UCM), to an extent that he drove the Black Theology project in association and partnership with some theology students (Sono 1993:29). It is of great interest to note, as Dolamo (2017:6) states, that Black Consciousness and Black Theology shared the same ideological basis to such an extent that conclusions such as the following were drawn: 'Black Theology ... is an extension of Black Consciousness' (Pityana 1972:41), 'Black Theology is the theological aspect of Black Consciousness' (Motlhabi 1972:55) and '(Some) ordinands and lay people were deeply influenced by Black Consciousness and its soulmate, Black Theology' (Duncan 2008:116). Powerful ideologies emanating out of Black Theology were used to invigorate a sense of Black Power (Ndaba \& Smith 2017:59). Within the SASO leadership, responsibilities were shared and Biko and Pityana were given the responsibility for political and theological matters (Wilson 1991:29). All these leaders were theologically inclined in addressing the disrespectful treatment towards black people's dignity and identity. Their integral involvement lays the foundation of justification for theology of dialogue to carry on in addressing hamartiological realities that cripple soteriological experiences for the black people's ecclesiological identities in South Africa. As Black Theology is situational and not time-bound, it continues to address new questions and confront new challenges as they arise. Motlhabi (1972:59) correctly points to the fact that Black Theology challenges black theologians to review what has been lost historically, culturally and religiously. Dolamo (2016:43) points to the fact that 'using Black Consciousness as a handmaid, Black Theology can meaningfully play a role in the democratic South Africa'. This new South Africa is marred with menaces such as poverty, racism, gender injustice, patriarchy, xenophobia, bad governance, environmental degradation etc. All these set the liberation agenda for Black Theology to play a prophetic role.

Black Theology has become a theology of hope for oppressed people in search of 'black solidarity and black dignity' (Lincoln 1974:112-113). Its contextualisation approach makes it a living discipline that needs to arise out of experiences, especially experiences that dehumanise human dignity and integrity. According to Boesak (1984), Black Theology does its theologising from the black experience:

$[B]$ lack theology is a black understanding of the gospel. This understanding is not confined to one group or denomination only, nor is it an automatic universal revelation to all Blacks. It is rather the result of a painful, soul-searching struggle of Black Christians with God and with the meaning of God's word for their lives today. (pp. 22-23)

There is a need for the return of Black Theology to the public arena in South Africa, not to compete with the prevailing ideologies rampant in a sociopolitical space, but to reestablish sense and theological integrity in South African corrupt social scenes. Racism is still rampant in South Africa. Inequality is visible in all socio-structural spheres of the society. Tensions and conflicts, violence and all kinds of criminal acts make daily news headlines. Indeed (Magaña cited in Sobrino \& Ellacuría 1996):

$[W]$ e have the conflicts and tensions that arise within a society that resists change, and in a church the majority of whose members are more accustomed to preserving the status quo than to proposing social transformation. (p. 178)

Theologically, South Africa as part of a global village exists climatically in post-Barthian, cross-cultural and interdisciplinary era. This is post-colonial, post-apartheid, democratic era and this calls for theological development that is vigorous prophetically and publicly (Roberts 1987:12). The needed theology is the one that is no more accepted as prepared, pre-packaged and shipped by Eurocentric white male theologians who are detached from the context of inequality and corruption in sociopolitical space.

\section{The current status}

South Africans are not immune from acts and experiences of dehumanisation, discrimination and devaluing of their cultural heritages that had left them in some sort of psychological disarray. The historical legacy of the unjust ideologies left some imprints and indelible marks on our national conscience. Mistrust, fear, uncertainties, etc., are deeply engrained in the hearts of many citizens. This is confirmed by Shutte (2001) that:

[T] he modern history of South Africa is a history of continuous inter-group and inter-cultural misunderstanding, leading to conflict and eventual disintegration and chaos in a state of permanent, sometimes open, sometimes hidden, war. (p. 223)

This status quo raises numerous questions. Some of the big questions in today's democratic and post-apartheid South Africa are as follows: 'Is there still Black Consciousness, Black Nationalism, and/or Black Theology in South Africa?' If so, how are the three manifested in public domain? Are they posing any danger to the nation-building attempts or quests to communion ecclesiology that the church is striving for in order to witness to the world that the church is one? The fact of the matter is that Black Consciousness, Black Nationalism and Black Theology are all not time-specific deliberations addressing the injustices that were rampant during the colonial and apartheid eras. The post-apartheid democratic South Africa is not the utopia attained or arrival into the Promised Land (Resane 2016:3). Black Consciousness and Black Nationalism express their existence and reality in 
current South Africa through political ideologies and formations. For instance, mentioning Black Consciousness, political parties that come to the mind include Pan Africanist Congress (PAC), Azanian People's Organisation (Azapo), Socialist Party of Azania (SOPA), African People's Convention (APC) and few others in small sporadic conglomerates. These parties are not doing well within the voters' base as they receive a very small percentage during the elections, as they receive zero, one or two seats in the National Assembly. Their ideology is still strong and significant in the masses on the ground. They represent the conscious ideology that stands in opposition to liberal ideals that are deemed to enhance the white monopoly capital that comes through white supremacist ideals. The white liberals still perceive them as elements of swart gevaar that promote revenge or re-opening of the wounds of injustices of the past.

The sentiments of Black Consciousness are also found within the ruling party, the ANC. This is evidenced by the former president of ANC Jacob Zuma's justification of factionalism within the party that 'ANC is a broader church' to mean that ANC is ideologically diverse. On the other hand, this in reality demonstrates that this factionalism is egoistic fragmentation and proliferation of preferences, where there is no unity. Black Consciousness in ANC is also presented by some leaders within it who come from Black Consciousness formations. African National Congress prominent figures, such as the former president Thabo Mbeki, proved to be unapologetically Black Conscious through his momentous 'I am an African'3 speech on 08 May 1996 during the adoption of the new Constitution of South Africa. The speech is clearly the expression of abhorrence of the injustices of the past but embracing the new era where equality and justice should prevail. Other known leaders from the Black Consciousness Movement include the likes of Alan Boesak, Frank Chikane, Nkosazana Dlamini-Zuma and so on. Bearing in mind that in the 1980s, the United Democratic Front (UDF) was composed of people from both ANC and Black Consciousness Movement, a host of clerical leaders were part and parcel of Black Theology Project. Most of these are still active in the sociopolitical and economic landscape of South Africa.

Black Nationalism is also very alive and active on South African sociopolitical landscape. There is an emergence of far-right politics with strong nationalistic Marxist orientations. Their ideology is the liberation of the poorest of the black masses from despair. For them, the working class must lead a proletarian revolution towards the abolishment of the private ownership of the land and replace it with the redistribution and nationalisation of basic industries and financial institutions. For these ideologues, this is the only means of reversing the detrimental economic legacy of apartheid and colonialism, which has strengthened the white monopoly capital, leaving black South Africans inherently disadvantaged.

3.See https://www.soweto.co.za/html/i_iamafrican.htm
The bottom line remains, as pointed out by Ramantswana (2016:182), that the issue of race can be neither evaded nor avoided, as it has to do with the question of who is producing knowledge. White privilege is everywhere if you open your eyes, years past it was obvious. For a white person in current South Africa to say he or she has not benefited from white privilege is to say that Prince Harry does not benefit from being a part of the royal family (McElhaney 2018:16). Colonial-apartheid racialisation remains a reality. South Africa is still on a journey of recovery from apartheid, hence ideological tensions escalated, and human relations jeopardised on the way. In the midst of all these blurry and uncertain situations, accompanied by escalating poverty, rampant unemployment, alcohol and drug abuse, personal and familial tragedies, many South Africans have turned to a solace of religion.

South Africa remains an economically unequal society full of injustices. Religion has provided compensation for people denied fulfilment of life and accessibility to livelihood resources such as food, water, shelter, etc. Even in this free democratic dispensation, there is a need for advocates of social justice, Black theologians who can provide victims of socio-economic inequalities the courage to claim their dignity and struggle for freedom in spite of the hopelessness of the real world in which they live' (Roberts 1987:107). Black Theology, using current elements and sentiments of Black Consciousness in South African society, 'can meaningfully play a role in the democratic South Africa' (Dolamo 2016:49).

\section{Is there a possibility for theology of dialogue?}

Nichols (2016:87) quotes Martin Luther that the time of silence is past, and the time to speak has come'. The current scenario of civil maladministration, poor governance, corrupt dealings of self-enrichment calls for a desperate need of theological dialogue involving the conscious nationalists and black theologians to address the plight of South Africans in the hands of few capitalist elites. Identifying and recognising the conflicts and struggles amongst actors (conscious, nationalists and theologians) with different backgrounds, cultures and ideological orientations may help to build up more dialogically oriented engagement that may lead to societal stability and harmony. Dialogue is crucial to confront the cultural diversity of South Africa by creating the possibility of cooperative meaning creation (Rathbone cited in Sands \& Verhoef 2018:95).

Black Theology like Comparative Theology 'is a practical response to political diversity read with eyes open, interpreting the context in light of Christian faith' (Clooney 2010:69) and with a willingness to be prophetic and curative at the same time. In other words, Black Theology should condemn and rebuke evil (prophetic) and intervene to heal the hurting world (reconciliation). Black Theology is called upon to play a corrective role in theological dialogue, engaging Black Consciousness aspirants and black nationalists. Theo-political dialogue 
points 'to actual conversations - formal, academic, interpersonal where dialogue partners are willing to listen to one another' (Clooney 2010:10) and share their stories of convictions and values. Theology of dialogue asserts itself through theo-political dialogues that may influence the communities about how to live in harmony with each other. This calls for political ideologues and theologians to embark on dialogical journey - a narrative that intends bringing peace, stability and harmony in the pluralistic society where some, especially those other than black, live under the delusion that blacks (swart gevaar) are planning some ethnic cleansing programmes. It is, therefore, imperative for Black Theology to remain living in connection with black political aspirations found in the communities.

Black Theology as a biblical theology preaches the gospel of love and peace. This love is both horizontal and vertical. It is love for God and for humanity. The significance of this biblical theology is the edification of the faith community in hearing and appropriating the scriptural teachings - the concern for these teachings not in abstracto, but in concreto, the actual human situation or human context (Torrance 1965:141) in which God through his Word has addressed his creation. Furthermore (Goto 2016):

[F]orming the faithful in dispositions of love must involve embodying prophetic imagination that transforms sinful cultures, processes and structures, leading to people existing with and for others. (p. 400)

This is one of the roles of Black Theology in current South Africa, which is populated by victims of social injustice from all cultural and racial backgrounds. It has to dialogue with itself to reflect on the re-evangelisation of black people, 'calling black people into self-acceptance, accepting themselves as created in the image of God (humanisation) and committing themselves to the struggle for justice' (Dolamo 2017:4). Here, we notice that today's Black Theology in South Africa must exhibit a deeply pastoral concern (Kritzinger 1988:172-197). The conscious and the nationalists are seated in both the green pastures (civil and corporate worlds) and slums of poverty (marginalised and forgotten) by those who ascended the upward ladder towards power apex of capitalism. Unfortunately, those grazing on the greener pastures forget that (Duchrow 2009):

[S]triving for wealth by destroying solidarity is the original sin of trying to judge on good and evil with the aim of erecting one's own righteousness and to grasp resources with violence instead of living together with others in the joy of the 'enough for all' out of the generously giving and liberating deity. (p. 42)

The pastoral concern for Black Theology includes entering into solidarity with the victims of apartheid by creating space for dialogue. After all, as Moltmann (1997:24) declares, '[l]ife is community, and community is the communication of life'. The dialogue partners (Black Consciousness aspirants, Black Nationalists and Black Theologians) should enter into dialogue in order to hear the voices of the voiceless, who are on the cutting edges of communities. The three grew up together and in some way brought each other up. They are friends on common ground, comrades in arms, as friends to be able to hear together the voices of those in desperation. There are cries of pain within the society, sloganeering for equality has faded, the previously disadvantaged leaders had entered the corridors of power and forgotten the 'comrades' who used to fight side-by-side with them in the cold culverts of poverty and shame. The cries are heard in the society; therefore, Black Theology must become the loudspeaker through which the cries can be transmitted to politicians in power. The agenda for the ensuing dialogue should be ' $[p]$ rophetic denunciation and public annunciation'. The first duty of love is to listen (Tillich 1960). Practising love through listening is 'a response to and participation in the freely given gift of Divine love' (Johnson 2018:280). It opens possibilities of dialogue across the walls of divisions.

Black Theology should engage a dialogic exchange oriented towards the expansive transformation of disciplinary imaginaries (Shahi 2020:167) that move beyond colonial and apartheid binaries of Africa versus colonialists. The nationalists' voices cannot continue to foster an exceptionalist dialogue which is narrowly applicable to the experiential realities of a native time-space zone as this jeopardises the spirit of racial harmony which is promoted by theology of reconciliation. Theology of dialogue always has an open door for all dialogical partners to enter the conference room and sit around the table to deliberate without elevating specific partners' experiences above others. Wolterstorff (2013:20) makes a theological appeal to this effect of articulating standpoints, whilst listening carefully and responsibly to whatever serious objections are raised by those who view things from a different standpoint. This calls for Black Theology to lead in 'structured settings to engage in facilitated dialogue aimed to help heal enmity, reduce prejudice, foster mutual understanding, and cultivate a more civil society' (Johnson 2018:279). Because it arose out of the context of violence against the status quo (Vellem in Chimhanda, Molobi \& Mothoagae 2015:91), it has the legitimate right to intervene in the current unfriendly and inhuman situations. Theologians from different persuasions seek to 'create inclusive, safe, and brave space' (Johnson 2018:281) so that dialogists share their stories and their identities, perspectives and values so that they can be understood, even if not agreed with. Through stories, dialogists could reveal what they had grown up with, their initial thinking, their recognitions, motivations, interests and the roots of their understanding. This enables them to become more aware of their common traits (justice and equality) and their collective unconscious (backlogs in fulfilling their inspirations) (Selçuk 2017:314). The fact of the matter is that the shared conviction is that only by talking together differently can we live together differently or live together at all (Johnson 2018:280). Emotions move dialogists dialogically from where they are to another place fostered by the reflection of reason and intuition. Logically, all perspectives should be allowed around the table. No world 
view should be privileged, a priori, in a way that discounts, without discussion, a proposal influenced by a differing world view (Heie 2008).

Black Theology's hermeneutical approach should be that of liberation (Baloyi 2019:54). This means that it should move with the church and go beyond its parameters, doing the best to lovingly remedy the injustice in socio-cultural structures, and especially economic differences, bringing the mind of God into the situation. Resane (cited in Sands \& Verhoef 2018:7) alludes to this: '[ $t]$ heologians are the transparent interlocutors of the mind of God in socio-economic structures of society'. Individual action is insufficient to deal with these inequalities and imbalances. Collective action is required and 'to be effective has to be political' (Bauer cited in Schaeffer 1985:330). Political freedom and freedom of faith are intertwined, the truth that is expressed by Moltmann (2015) that:

$[T]$ he freedom of faith is lived out in political freedom. The freedom of faith therefore urges men towards liberating actions, because it makes them painfully aware of suffering in situations of exploitation, oppression, alienation and captivity. (pp. 331-332)

Engaging dialogically with conscious aspirants and nationalists, Black Theology can accomplish much, mirroring the New Testament apostolic church methods of communication (dialegomai) - dialogical interaction between the speakers and the respondents (Hesselgrave 1980:212). In this current debate, it is a dialogue between the black conscious nationalists and the white supremacists (colonialists, apartheid proponents and normativists). After all, the New Testament churches were the communities of moral discourse by being communities of moral deliberation. They not only discoursed, but also deliberated and promoted communality. They talked together (dialogue) about what and why to do. They emphasised the why of their actions rather than doing nothing (Verhey cited in Husbands \& Trier 2005:149). Colonial Christianity failed to display this morality in many ways, hence the universal call that the sooner the identification of Christianity with colonialism is dropped, the better it will be for the cause of Christ. The wrong practices of earlier missionaries, who interpreted the truth wrongly, should not cause us to put aside the truth of the Gospel that does not change (Fernando 1995:104). This is where Black Theology is to exert itself.

\section{Conclusion}

The reality is that Black Consciousness, Black Nationalism and Black Theology are expressively prevalent in the South African society. Democracy gives it another colour or shape, but aspirations are felt and experienced. Ascendancy to political power by the aspirants during the colonial and apartheid eras created some form of dormancy that has silenced the aspirations of justice and equality. Corruption, maladministration, bad governance, marginalisation of the poor, nepotism and many societal evils are mushrooming at an alarming rate. Knowledge about these menaces is obvious, but as Balenga (2017:231) says, ' $[k]$ nowledge must be put into action, or it is of no value'.

South Africa is becoming a peasant society, poverty is escalating and people feel defenceless as safety and security for ordinary citizens is unreliable. Race relations are still a far-fetched dream and capitalism where the rich become richer (most at the expense of the poor) and the poor become poorer. The multicultural dream envisaged by the liberation fighters is evaporating in political mists and smokes. Binaries in society cause a serious ripple effect dividing the haves and the have-nots. Black theologians must enter the foray by inviting some serious dialogue with the nationalists to chart the way towards sociopolitically emancipated South Africa. The boardroom door must be open, and the table for dialogue must be made accessible to Black Consciousness, Black nationalists and Black theologians as dialogical partners to try to sensitise South Africa towards social justice encompassing equality, ethical sensibilities and restoration of humane identities. This will to some extent open the way to prosperity, as Balenga (2017:235) asserts, ' $[t]$ his is not a romantic egalitarian dream, but a requirement of all societies that want to prosper'. The current situation creates some opportunities for theology of dialogue to assert and exert itself.

\section{Acknowledgements Competing interests}

The author declares that he has no financial or personal relationships that may have inappropriately influenced him in writing this article.

\section{Author's contributions}

K.T.R. is the sole author of this research article.

\section{Ethical considerations}

This article followed all ethical standards for research without direct contact with human or animal subjects.

\section{Funding information}

This research received no specific grant from any funding agency in the public, commercial or not-for-profit sectors.

\section{Data availability}

Data sharing is not applicable to this article as no new data were created or analysed in this study.

\section{Disclaimer}

The views and opinions expressed in this article are those of the author and do not necessarily reflect the official policy or position of any affiliated agency of the author. 


\section{References}

Balenga, C.B.M., 2017, Africa, it's time, My Legacy on Record, Edmonton.

Baloyi, T.G., 2019, 'Doing theology in the context of poverty in South Africa: A reading of James Cone's black theology of liberation', Journal of Theology for Southern Africa $162 \& 163,46-55$

Bauer, P.T., 1985, 'Ecclesiastical economics: Envy legitimized', in F. Schaeffer (ed.), Is capitalism Christian? Toward a Christian perspective on economics, pp. 327-343, Crossway Books, Westchester, IL.

Biko, S., 1978, 'I write what I like', in A. Stubbs (ed.), Picador Africa, Johannesburg.

Boesak, A., 1984, Black and reformed: Apartheid, liberation and the Calvinist tradition, Skotaville, Johannesburg.

Boesak, A., 2005, The tenderness of conscience: African renaissance and the spirituality of politics, Sun Press, Stellenbosch.

Cloete, M., 2016, 'Allan Boesak: Innocence and the struggle for humanity', Acto Theologica 36(Suppl. 24), 17-42. https://doi.org/10.4314/actat.v36i1.3S

Clooney, F.X., 2010, Comparative theology: Deep learning across religious borders, Wiley-Blackwell, Malden.

Cone, J., 1972, 'Black theology and black liberation', in M. Motlhabi (ed.), Essays on black theology, pp. 28-36, UCM, Johannesburg.

Dolamo, R.T., 2014, 'Botho/Ubuntu: Perspectives of black consciousness and black theology', Studia Historiae 40(Suppl. 1), 215-229. https://doi.org/10.7833/112-0-78

Dolamo, R.T., 2017, 'The legacy of black consciousness: Its continued relevance for democratic South Africa and its significance for theological education', HTS Teologiese Studies/Theological Studies 73(3), a4587. https://doi.org/10.4102/hts. v73i3.4587

Dolamo, R.T.H., 2016, 'Does black theology have a role to play in the democratic South Africa?', Acta Theologica 36(Suppl. 24), 43-61. https://edoi.org/10.4314/ actat.v36i1.4S

Duchrow, U., 2009, 'The people of God in the context of imperial politics, economics, and ideology in biblical and ecumenical perspective', Journal of Theology for Southern Africa 134, 35-52.

Duncan, G., 2008, 'Steve Biko's religious consciousness and thought and its influence on theological influence with special reference to the federal theological seminar of Southern Africa', Papers presented at the Forum for Religious Dialogue Symposium of the Research Institute for Theology and Religion, University of South Africa, Pretoria, 23-24 August, 2008, pp. 115-140.

Encyclopedia.com, n.d., Nationalism, Africa, viewed 13 October 2020, from https:// www.encyclopedia.com/history/encyclopedias-almanacs-transcripts-and-maps/ www.encyclopedia.co
nationalism-africa.

Fernando, A., 1995, The supremacy of Christ, Crossway Books, Wheaton, IL.

Gerhart, G.M., 1979, Black power in South Africa: The evolution of an ideology University of California Press, Oakland, CA.

Giliomee, H., 2003, The Afrikaners: Biography of a people, Tafelberg \& NB Publishers, Cape Town.

Goto, C.T., 2016, 'Teaching love: Embodying prophetic imagination through clowning', Religious Education 111(4), 398-414. https://doi.org/10.1080/00344087.2016.11 83160

Heie, H., 2008, 'Dialogic discourse: Christian scholars engaging the larger academy', Christian Scholar's Review XXXVII(3), 347-356.

Hesselgrave, D.J., 1980, Planting churches cross-culturally: A guide for home and foreign missions, Baker Book House, Grand Rapids, MI.

Johnson, S., 2018, 'Speaking together differently to live together differently: The promise of the public dialogue movement', Religious Education 113(3), 277-288. https://doi.org/10.1080/00344087.2018.1455568

Jordan, Z.P., 2007, Oliver Tambo remembered, Pan Macmillan, Johannesburg.

Kenworthy, P.C., 2007, 'Bikoism or Mbekism: The role of black consciousness in Mbeki's South Africa', Master's thesis, International Development Studies and Kirsten Holst Petersen, English Roskilde University, Trekroner.

Kohn, H., 1965, Nationalism: Its meaning and history, rev. edn., Van Nostrand Princeton, NJ.

Kritzinger, J.N.J., 1988, 'Black theology: A challenge to mission', DTh thesis, Department of Missiology, University of South Africa.

Lamola, M.J., 2016, 'Biko, Hegel and the end of black consciousness: A historicophilosophical discourse on South African racism', Journal of Southern African Studies 42(2), 183-194. https://doi.org/10.1080/03057070.2016.1135672

Lincoln, C.E., 1974, The black church since Frazier, Schocken Books, New York, NY.

Magaña, A.Q., 1996, 'Ecclesiology in the theology of liberation', in J. Sobrino \& I. Ellacuría (eds.), Systematic theology: Perspectives from liberation theology, pp. 178-193, Orbis Books, Maryknoll, NY.

Magaziner, D.R., 2010, The Law of the Prophets: Black consciousness in South Africa 1968-1977, Ohio University Press, Athens.

Mahlatsi, M.L.S., 2020, Corridors of death: The struggle to exist in historically white institutions, Blackbird Books, Polokwane.

Mbeki, T., 1996, I am an African, viewed 16 August 2020, from https://www.soweto. co.za/html/i_iamafrican.htm.

Mbembe, A., 2017, Critique of black reason, transl. L. Dubois, Wits University Press, Johannesburg.

McElhaney, J., 2018, Racism in the White Church: Still smoldering under the ashes, Createspace Independent Publishers, Scotts Valley, CA.
Mkandawire, T. (ed.), 2005, African intellectuals: Rethinking politics, language, gender and development. Modern democracy, Harper and Brothers, New York, NY.

Moltmann, J., 1997, The source of life: The holy spirit and the theology of life, Fortress Press, Minneapolis, MN.

Moltmann, J., 2015, The crucified god, 40th anniversary edn., SCM Press, London.

Motaung, T., Moleketi, T., Mokoele, D. \& Mangena, N., 2000, 'The convergence of history and theoretical paradigms: Reflections on geopolitics shaping the African continent', in F. Kornegay Jr. \& P. Mthembu (eds.), Africa and the world: Navigating shifting geopolitics, pp. 54-77, Mapungubwe Institute for Strategic Reflection shifting geopolitics, pp.
(MISTRA), Johannesburg.

Motlhabi, M., 1972, 'Black theology', in M. Motlhabi (ed.), A personal opinion, pp. 53-59, University Christian Movement, Johannesburg.

Ndaba, B. \& Smith, J., 2017, 'Steve Biko and the rise of black consciousness', in B Ndaba, T. Owen, M. Panyane, R. Serumula \& J. Smith (eds.), The black consciousness reader, pp. 23-63, Jacana Media, Auckland Park.

Netshitenzhe, J., 2020, 'The multiple determinants of geopolitics and Africa's place in a potent economic, ideological and psychological mix', in F. Kornegay Jr. \& P. Mthembu (eds.), Africa and the world: Navigating shifting geopolitics, pp. 20-52, Mapungubwe Institute for Strategic Reflection (MISTRA), Johannesburg.

Nichols, S.J., 2016, Beyond the 95 theses: Martin luther's life, thought, and lasting legacy, P\&R Publishing, Phillipsburg, NJ.

Pityana, N.B., 1972, 'What is black consciousness?', in M. Motlhabi (ed.), Essays on black theology, pp. 37-43, University Christian Movement, Johannesburg.

Pityana, N.B., Ramphele, M., Mpumiwana, M. \& Wilson, L. (eds.), 1992, 'Learning from Robben Island: The prison writings of Govan Mbeki', in Bounds of possibility: The legacy of Steve Biko and black consciousness, p. 256, Zed Press, New York, NY.

Ramantswana, H., 2016, 'Decolonising biblical hermeneutics in the (South) African context', Acta Theologica 36(Suppl. 24), 178-203. https://doi.org/10.4314/actat. v36i1.4s

Ramphele, M., 1995, Across boundaries: The journey of a South African woman leader, The Feminist Press, New York, NY.

Rathbone, M., 2018, 'Adam Smith, the impartial spectator and embodiment: Towards and economics of accountability and dialogue', in J. Sands \& A.H. Verhoef (eds.), Transforming encounters and critical reflection: African thought, critical theory, and liberation theology in dialogue, pp. 89-100, Multidisciplinary Digital Publishing Institute, Basil.

Resane, K.T., 2016, “'Ichabod" - The glory has departed: The metaphor showing the church's prophetic failure in South Africa', Pharos Journal of Theology 97, 1-12.

Resane, K.T., 2018, 'Transparent theological dialogue - "Moseka Phofu Ya Gaabo Ga a Tshabe Go Swa Lentswe" (A Setswana Proverb)', in J. Sands \& A.H. Verhoef (eds.), Transforming encounters and critical reflection: African thought, critical theory, and liberation theology in dialogue, pp. 6-16, Multidisciplinary Digital Publishing Institute, Basil.

Roberts, J.D., 1987, Black theology in dialogue, Westminster Press, Philadelphia, PA.

Selçuk, M., 2017, 'God will tell you the truth regarding your differences', Religious Education 112(4), 312-316. https://doi.org/10.1080/00344087.2017.1320500

Shahi, D., 2020, 'Foregrounding the complexities of a dialogic approach to global international relations', All Azimuth 9(2), 163-176. https://doi.org/10.20991/ allazimuth. 725230

Shutte, A., 2001, UBUNTU: An ethic for a new South Africa, Cluster Publications, Pietermaritzburg.

Sithole, N., 1968, African nationalism, 2nd edn., Oxford University Press, New York, NY.

Smith, J., 2017, 'Black consciousness and Christianity', in B. Ndaba, T. Owen, M. Panyane, R. Serumula \& J. Smith (eds.), The black consciousness reader pp. 102-138, Jacana Media, Auckland Park.

Sono, T., 1993, Reflections on the origins of black consciousness in South Africa, Human Science Research Council, Pretoria.

South African History Online, n.d., African nationalism and working-class \& popular protests, 1910-1924, viewed 10 August 2020, from https://www.sahistory.org.za/ article/african-nationalism-and-working-class-popular-protests-1910-1924.

'The Rise of Black Nationalism', The Black Sash, August, 1976, pp. 25-28.

Thomas, D., 2002, Christ divided: Liberalism, ecumenism and race in South Africa, University of South Africa, Pretoria.

Tillich, P., 1960, Love, power, and justice, Oxford University Press, New York, NY.

Torrance, T.F., 1965, Theology in reconstruction, W.B. Eerdmans Publishing Company, Grand Rapids, MI.

Tshaka, R.S. \& Makofane, M.K., 2010, 'The continued relevance of black liberation theology for democratic South Africa today', Scriptura 105(2010), 532-546. https://doi.org/10.7833/105-0-155

Vellem, V., 2015, 'From mission to stewardship: The social analysis of black mission in the context of empire', in F.H. Chimhanda, V.M.S. Molobi \& I.D. Mothoagae (eds.), African theological reflections: Critical voices on liberation, leadership, gender and eco-justice, pp. 86-103, UNISA, Pretoria.

Verhey, A., 2005, 'Able to instruct one another: The church as a community of moral discourse', in M. Husbands \& D.J. Treier (eds.), The community of the word: Toward an evangelical ecclesiology, pp. 146-172, InterVarsity Press, Downers Grove, IL.

Williams, D., 1970, 'African nationalism in South Africa: Origins and problems', The Journal of African History 11(3), 371-383. https://doi.org/10.1017/\$0021853700010203

Wilson, L., 1991, 'Bantu Stephen Biko: A life', in N.B. Pityana \& M. Ramphele (eds.), Bounds of possibility: The legacy of Steve Biko \& black consciousness, pp. 15-77, David Philip, Cape Town.

Wolterstorff, N.P., 2013, Journey toward justice: Personal encounters in the global south, Baker Academic Books, Grand Rapids, MI. 